This item was submitted to Loughborough's Research Repository by the author.

Items in Figshare are protected by copyright, with all rights reserved, unless otherwise indicated.

\title{
Reflexive self-identity and work: working women, biographical disruption and agency
}

PLEASE CITE THE PUBLISHED VERSION

https://doi.org/10.1177/0950017020926441

PUBLISHER

SAGE Publications

VERSION

AM (Accepted Manuscript)

\section{PUBLISHER STATEMENT}

This paper was accepted for publication in the journal Work, Employment and Society and the definitive published version is available at https://doi.org/10.1177/0950017020926441. Users who receive access to an article through a repository are reminded that the article is protected by copyright and reuse is restricted to non-commercial and no derivative uses. Users may also download and save a local copy of an article accessed in an institutional repository for the user's personal reference. For permission to reuse an article, please follow our Process for Requesting Permission.

\section{LICENCE}

In Copyright

\section{REPOSITORY RECORD}

Trusson, Diane, Clive Trusson, and Catherine Casey. 2020. "Reflexive Self-identity and Work: Working Women, Biographical Disruption and Agency". Loughborough University. https://hdl.handle.net/2134/12173619.v1. 


\title{
Reflexive self-identity and work: working women, biographical disruption and agency
}

Diane Trusson, Faculty of Medicine and Health Sciences, University of Nottingham, UK

Clive Trusson, School of Business and Economics, Loughborough University, UK

Catherine Casey, School of Business and Economics, Loughborough University, UK

This article was accepted for publication in a future issue of Work, Employment and Society on 18th April, 2020.

\begin{abstract}
The article examines how women workers reflexively shape their self-identities and work identities following a significant biographical disruption incurred by breast cancer diagnosis and treatment. Based on interviews with 22 women navigating their post-diagnosis life course, the article addresses participants' challenges in their relationships with paid employment, their responses, and self-identity narratives. It finds that women strive to revise and innovate their self-identity and work identity in the midst of personal and social constraints in working life. They craft their cancer disruptive experiences into new developments of who they are, and want to be, as persons and as workers. Multiple intersectional features of participants' work-related self-identity are identified, including reassessment of priorities, capabilities, and workplace relations.
\end{abstract}

Keywords: biographical disruption; breast cancer; self-identity; sick role; work relationships

\section{Corresponding author:}

Diane Trusson, NIHR Applied Research Collaboration - East Midlands (ARC-EM), University of Nottingham Innovation Park, Triumph Road, Nottingham, NG7 2TU Email: Diane.Trusson@nottingham.ac.uk 


\section{Introduction}

Research debates on identity at work prominently include inquiry into how work, occupation, and organisation affect the shaping and utility of workers' self and collective identities (Casey, 1995; MacKenzie and Marks, 2019; Strangleman, 2012). Exploration of questions of gender, race, ethnicity, and national culture have added further insight into the challenges and complexities of managing identity expression in work and employment contexts (Alvesson and Billing, 2009; Chandler, 2017; Mickey and Wingfield, 2019).

In regard to gender, much debate has addressed gender differences in orientations to work (Crompton and Harris, 1998; Zou, 2015), occupational opportunity (Andringa et al., 2015; Glauber, 2011) and traditional conflicts between work and family interests and women's self-identity in both domains. Gender differences are observed, too, in aging and retirement (Ní Léime et al., 2017; Wildman, 2019). A further stream of research explores how disruptive life events or personal predicaments affect self-identity (Watson, 2008) in particular regard to a person's work and employment context. Importantly, there is much attention on workers' experience and challenges to self-identity following circumstances of unchosen unemployment such as redundancy, plant closure, or occupational displacement (Blyton and Jenkins, 2012; Gardiner et al. 2009; MacKenzie and Marks, 2019). In a parallel vein, sociologies of health and illness draw further attention to questions of biographical disruption (Baker et al. 2014; Bury, 1982, 1991, Foubert et al, 2016; Sanders et al., 2019) that arise when people experience disruptive ill health such as a chronic illness or lifethreatening disease. Addressing the intersection of biographical disruption through a significant health event and an individual's working life proposes to add advanced knowledge to debate on self-identity and work.

Breast cancer is the most common life-threatening disease to affect working-age women in the UK. Although incidences have increased in recent decades, survival rates have 
also significantly increased (CRUK, 2020). Recently, breast cancer has gained a high media profile through advocacy groups and increased medical research attention. These factors, in the context of increased female workforce participation, affect experience and expectations of women working during and after breast cancer treatment. Many women resume work on completion of hospital-based treatments for early breast cancer (i.e. cancer that has not spread beyond the breast region). Research suggests that this is frequently a challenging experience (McKay et al. 2013; Peterson et al. 2018; Tiedtke, 2012), with concerns expressed about being accepted back into work roles, capability, vulnerability (Powers et al. 2016; Tamminga et al. 2012; Tiedtke, 2012) and illness perceptions (Kaptein et al. 2015). Studies also show that there are particular societal expectations associated with the experience of breast cancer. As Powers et al. (2016) point out, a public discourse in which women 'survivors' of breast cancer are applauded by campaigns of 'pink positivity' (in reference to the proliferation of pink ribbon symbols for positivity and triumph) is in tension with persistent cultural unease or stigmatisation of cancer experiencers (Balmer et al. 2014; Ehrenreich, 2009; Stergiou-Kita et al., 2016).

In this article, the analytical focus is concerned with women's experiences in relation to work following diagnosis and treatment of early breast cancer. Extant research has identified factors and challenges in regard to return to work but there is scarce attention to the role of self-identity in affecting women's revised relations with their work and employment relationships. This article addresses that gap in the literature through an inquiry into how, during and after breast cancer treatment, women shape their self and work identities in personally altered circumstances. In doing so, it builds on research indicating that an unexpected diagnosis of breast cancer can disrupt multiple aspects of women's lives, including self-identity and future plans (Lally and Underhill, 2012; Little et al., 2000; Trusson et al., 2016). This article focuses attention on reflexive narrative accounts of 
disruption to, and reshaping of, work roles and identities. It shows how women reflexively revise and re-shape their self-identity, and relatedly take new actions in their biographical paths.

The article is structured as follows: the literature on self-identity and biographical disruption theory is reviewed. These concepts provide the framework for analysing this qualitative study of women's subjectivities following breast cancer diagnosis and treatment. The literature regarding cancer treatment and work is discussed and the empirical study and research methodology introduced. Discussion and interpretative analysis of findings and brief conclusion follow.

\section{Biographical Disruptions and Changing Self-identities}

Work and occupation have long been posited as important features of identity (Bauman, 2001; Beck and Beck-Gernshien, 2002; Giddens, 1991). Such debates on identity have emphasised not only its individual aspects but also social and collective, notably in regard to class and occupation as well as to traditional gendered divisions of labour that shape individuals' self-identities (Casey, 1995). Gainful work, whether in paid or (voluntarily) unpaid employment continues to provide individuals with a source of intrinsic worth and social affiliation and belonging (Doherty, 2009; Taylor, 2004; 2015). Detrimental changes to work situations (e.g. job loss) are frequently associated with economic, social and selfidentity disruption (MacKenzie and Marks, 2019) and, when experienced collectively, to community fracture and social decline (Dobbins et al. 2014; Trusson and Woods, 2016).

Notably, Giddens argues that it is necessary for self and social well-being for individuals to achieve a reliable sense of self-identity. For Giddens (1991:54), the 'existential question of self-identity' is bound up with the fragile nature of biography. The individual's 'ontological security', which is a sense of continuity or consistency of oneself, is the basis of self-identity. Threats to that can significantly affect an individual's social well-being and 
health. The individual must develop the capacity to 'keep a particular narrative going'. In so doing the self becomes 'a reflexive project' across the course of life in which a robust selfidentity may 'weather major tensions or transitions' (Giddens, 1991:32,55).

The term 'identity work' is often used to denote the reflexive efforts of the individual in maintaining her/his sense of self-identity and her/his positions within social arenas (Bauman, 2001; Riach and Loretto, 2009; Watson, 2012). Watson (2012:257) refers to identity work being 'a process whereby people strive to shape a relatively coherent and distinctive notion of self-identity'. The temporal/biographical dimension of identity work as a 'process of self-making' (Stahl, 2015:60) implies that it might entail coming to terms with disruptive events as 'impositions or threats to identity' (Beech et al., 2016:508) (e.g. cancer diagnosis and subsequent treatments) and, in those changed circumstances, responding to the reflexive question of 'what is best 'for me' as an individual' living in the present and planning a future? (Atkinson, 2016:893). Such work may be deliberately enacted in response to a significant disruption to routines, 'life plans' (Giddens, 1991:85) (including career), and status (including that afforded by work), and enable the recrafting of those 'life plans' and self-identity narratives.

In accordance with these debates, sociology of health and illness research frequently utilises Bury's (1982) concept of biographical disruption (Johnsson et al., 2010; Wilson, 2007; Trusson et al., 2016). The concept, which echoes Giddens' (1991) depiction of challenges to 'ontological security', refers to how structures of an individual's everyday life, taken-for-granted assumptions, plans and expectations can be disrupted by a medical diagnosis. It has also been employed to discuss how bodily disfigurement can disrupt selfidentity and work identity (Martindale and Fisher, 2019). The 'critical situation' of a diagnosis of a significant, potentially life-threatening illness, constitutes 'a form of biographical disruption' and triggers a 'fundamental rethinking of biography and self- 
concept' (Bury, 1982:169). Particular identity work is stimulated in recognition that social and work relationships, roles and routines have altered. This reflexive work remains connected to past identity (Brown, 2015) but with the intention of 'repairing, maintaining, strengthening or revising' the individual's authentic sense of self and biographical selfnarrative (Ibarra and Barbulescu, 2010; Sveningsson and Alvesson, 2003:1165).

\section{Disruptive illness, breast cancer treatment, and work}

Research on disruptive illness experience has found much utility in Parsons' (1951) wellknown sick role theory. Parsons recognised that illness is both biologically and socially defined; it includes a moral connotation against 'malingering'. The theory proposes that people occupying 'the sick role' are exempted from 'performing their normal social roles' while being 'obligated to want to get well as soon as possible' (Scambler, 1991:186). Medical sociology researchers contend that despite the critique of Parsons' functionalist analysis, sick role theory has found an enduring influence in work, organisation, and employment management practices (Kennedy et al., 2007). Sick leave policies frequently implicitly retain the dichotomous assumption that workers are either sick or they are well.

Bury's (1982) theory that illness disrupts biography implicitly problematises the assumption of either a resumption of wellness after sickness (i.e. return to a pre-illness biographical state), or a permanent state of sickness or incapacity. A serious diagnosis exposes an embodied ontological frailty to the self and, in the workplace, to managers and colleagues. Adjustment and integration of that entails unpredictability and contingency and brings into question the dichotomous assumption. While most sick leave policies address more common sickness experiences, in the case of cancer, statutory regulation may provide further protections. In the UK, the Equality Act, 2010, requires employers to 'make reasonable adjustments' to working practices for employees following a cancer diagnosis 
(e.g. modifications to job description and performance targets; flexible hours), including where treatments have been successful (MacMillan, 2019). While phased return from sick leave is one such 'reasonable adjustment', expectations that a worker will, or can, resume pre-diagnosis and pre-systemic treatment work roles under altered personal conditions are questionable (Banning, 2011).

Women are more likely than men to face a cancer diagnosis in their 30s, 40s and 50s (i.e. while in paid work) (Pudrovska, 2010). A breast cancer diagnosis is frequently experienced as 'a profound shock' to the woman, especially the younger woman (Pudrovska, 2010:535). (Men may, rarely, be similarly diagnosed but their case is not addressed in this study.) Such a diagnosis triggers a series of disruptive treatment events that may include surgery (lumpectomy/mastectomy); chemotherapy; radiotherapy; hormone treatment; and/or breast reconstruction surgery (MacMillan, 2019). These treatments may be lengthy and intermittent and may be unpredictable in their effects. Consequently, presumption that a worker diagnosed with cancer will have a single or even two-phased 'return to work' event (Cooper et al., 2013; Yarker, et al. 2010) is problematic.

Most women are considered well enough to resume work after hospital-based treatments finish, but non-visible physical and psychological consequences can persist long after treatment cessation (Tighe et al., 2011). This suggests multiple and/or persistent biographical disruptions. These biographical disruptions, through the cancer experience and its social attributions (from stigma to positivity and triumph (Trusson and Pilnick, 2017), significantly affect the individualised life project. The pre-illness state has passed into history. The individual must find her way to integrate that and subsequent effects of the illness into a new self-narrative. That may entail re-assessment of life priorities and aspirations including in regard to her work and employment situation. At this sense-making interchange of information, the fragile biography 'which the individual 'supplies' about 
herself' (Giddens, 1991:54) may 'break down’ (Beck and Beck-Gernsheim, 2002)

precipitating particular self-identity work to be undertaken so that identity and biography can be re-made to fit each other (Bauman, 2001). However, to speak of specific 'points' of 'biographical break down' and 'identity change' (Beech, 2011) eludes the nuances and nonlinearity of identity revision and innovation. Thus, plans for future life (including work) may be construed as being perpetually in flux, continually being reworked to prepare 'a course of future actions mobilised in terms of the self's biography' (Giddens, 1991:85).

Women returning to work after breast cancer face a mix of personal and public narratives through which they endeavour to craft a revised sense-making self-identity narrative. Research highlights difficulties they face in regard to perceptions of altered bodies, physical capabilities, relationships, and social expectations (Nielsen, 2019; Trusson et al., 2016). The experience of cancer diagnosis and treatment is frequently shown to trigger a change in work and life priorities with health and family time accorded greater importance vis-à-vis work and career (Amir et al., 2008; Kennedy et al., 2007; McKay et al., 2013). Recovery from breast cancer treatments includes recovery from fatigue which is a notable effect that may last for years after treatment finishes (Godfrey et al, 2018). At the same time, research reports self and social expectations for women to be 'back to normal' when they return to work (residual of Parsons' 'sick role' binary positions socially-embedded in organisational practices) (Kennedy et al., 2007). Individuals may present as being well. Furthermore, they may feel obligated to present the positivity and triumph of 'survivor' status that is particularly demanded of breast cancer experiencers. As an effect of concerted publicity campaigns to raise the profile of breast cancer and increased medical science and healthcare attention, a particular 'survivor' discourse of positivity can, ironically, inhibit breast cancer patients from disclosing difficulties that they experience (Trusson and Pilnick, 2017). 
Extant research on women's adjustments after breast cancer disruption and of factors affecting their return to work has frequently focused on practical arrangements and management interventions. Rarely considered are the challenges to self-identity associated with the biographical disruption of life-threatening diagnosis and subsequent demanding treatment. Relatedly, there has been inadequate focus on how women act to shape their revised self and work identities. This research asks: How do women reflexively shape their self-identity and work identity during and after treatment for early breast cancer?

\section{Research method}

The data discussed in this article come from a UK-based study of 22 women's accounts of their experiences following early breast cancer diagnoses. The study aimed to explore participants' subjectivities via the stories they tell (Hoyer and Steyaert, 2015; Shakespeare, 1996). Narrative approaches can reveal how individuals construct and express their identities (Alvesson and Kärreman, 2007; Foster D, 2007; Foster K, 2012; Ibarra and Barbulescu, 2010; Martindale and Fisher, 2019). Women who had been treated for early breast cancer were recruited for the study via local newspapers and radio broadcasts, and a university website. Consequently, the study's population sample was initially a self-selected group. This was confirmed to be a purposive sample (Silverman, 2010) of women who, at time of diagnosis, were employed (17), self-employed (3), or of working-age but not employed (2). The average participant age at the time of diagnosis was 47 (median $=45$; range $=39-62$ ) and at the time of interview was 53 (median $=51$; range $=42-75$ ). The average time difference between diagnosis and interview, reflecting the scope of each participant's narrative, was 6 years $($ median $=5$; range $=1-29$ ). Table 1 includes details pertaining to each of the participants including their ages at diagnosis and interview and draws on the narratives to provide a set of brief work and employment biographies from diagnoses to interviews. 


\begin{tabular}{|c|c|c|c|c|c|c|}
\hline $\begin{array}{l}\text { Name } \\
\text { (*indicates } \\
\text { pseudonym) }\end{array}$ & $\begin{array}{l}\text { Age at } \\
\text { Diagnosis }\end{array}$ & $\begin{array}{l}\text { Years } \\
\text { between } \\
\text { Diagnosis } \\
\text { and Interview }\end{array}$ & $\begin{array}{l}\text { Employment } \\
\text { Status when } \\
\text { Diagnosed }\end{array}$ & $\begin{array}{l}\text { Employment } \\
\text { Status when } \\
\text { Interviewed }\end{array}$ & $\begin{array}{l}\text { Work Situation when } \\
\text { Diagnosed }\end{array}$ & Subsequent Work/ Employment Biography \\
\hline Malaika & 39 & 6 & Part-time & Part-time & $\begin{array}{l}\text { Recently started an } \\
\text { enterprise partnership } \\
\text { running 'wellness' house } \\
\text { parties }\end{array}$ & $\begin{array}{l}\text { Did not pursue business enterprise. Found part- } \\
\text { time work in a takeaway food outlet. }\end{array}$ \\
\hline Phoebe* & 39 & 6 & Part-time & Part-time & University librarian & $\begin{array}{l}\text { Returned to work initially four weeks after } \\
\text { surgery but 'signed-off' for lengthy periods over } \\
\text { the next year. Remains in same role. }\end{array}$ \\
\hline Sam & 40 & 2 & Full-time & Part-time & $\begin{array}{l}\text { Employed by health charity } \\
\text { (not cancer-related), } \\
\text { mainly working from home }\end{array}$ & $\begin{array}{l}\text { The charity imposed a part-time contract on } \\
\text { return to work. Does additional voluntary work } \\
\text { for a cancer charity. Considering career as } \\
\text { nutritionist. }\end{array}$ \\
\hline Viv* & 40 & 4 & Part-time & Part-time & $\begin{array}{l}\text { Administrator for family } \\
\text { business (sole trader) }\end{array}$ & Has continued to work as before. \\
\hline Kate* & 41 & 6 & Full-time & Full-time & University administrator & Returned to work at earliest opportunity. \\
\hline Carol * & 42 & 8 & Full-time & Part-time & $\begin{array}{l}\text { Employed within hospital } \\
\text { printing services unit }\end{array}$ & $\begin{array}{l}\text { Two years after surgery went back to work } \\
\text { briefly but was unable to cope with lifting } \\
\text { requirements of the role. Subsequently attempted } \\
\text { to earn an income as reflexologist and slimming } \\
\text { club leader. Started nursing training but } \\
\text { withdrew. }\end{array}$ \\
\hline Gabrielle & 42 & 3 & Full-time & Part-time & $\begin{array}{l}\text { Owner-manager of holistic } \\
\text { healing centre }\end{array}$ & $\begin{array}{l}\text { Closed business and subsequently worked for } \\
\text { charity supporting homeless people. Also does } \\
\text { mental health voluntary work. }\end{array}$ \\
\hline
\end{tabular}




\begin{tabular}{|c|c|c|c|c|c|c|}
\hline Karen & 42 & 1 & Full-time & $\begin{array}{l}\text { Full-time } \\
\text { (on sick } \\
\text { leave) }\end{array}$ & Social worker & Planning phased return to work. \\
\hline Connie* & 44 & 7 & Part-time & Not working & Swimming instructor & $\begin{array}{l}\text { Physically unable to continue in her role. } \\
\text { Involved in running a charity supporting a } \\
\text { hospital ward for breast cancer patients. }\end{array}$ \\
\hline Sophie* & 44 & 5 & Full-time & Full-time & University manager & Returned to work after recovery from operation. \\
\hline Catherine & 45 & 2 & Full-time & Part-time & $\begin{array}{l}\text { Had recently started a new } \\
\text { charity-sector job }\end{array}$ & $\begin{array}{l}\text { Left job during chemotherapy treatment. Now } \\
\text { school counsellor. Also trained as a volunteer } \\
\text { 'breast cancer care facilitator'. }\end{array}$ \\
\hline Jean & 46 & 29 & Part-time & Not working & $\begin{array}{l}\text { University administrator } \\
\text { (casual work) }\end{array}$ & No work since. \\
\hline Maggie & 49 & 7 & Full-time & Full-time & Student careers adviser. & Returned to work at earliest opportunity. \\
\hline Sandra & 49 & 9 & Full-time & Full-time & University librarian & Returned to work at earliest opportunity. \\
\hline Wendy & 49 & 2 & Full-time & Full-time & $\begin{array}{l}\text { Intensive care } \\
\text { nurse/manager }\end{array}$ & Phased return to work. \\
\hline Nina* & 50 & 3 & Full-time & Part-time & $\begin{array}{l}\text { Local government } \\
\text { administrator }\end{array}$ & Phased return to work. Later reduced hours. \\
\hline Martha* & 53 & 5 & Full-time & Full-time & University manager & Returned to work at earliest opportunity. \\
\hline Tina* & 53 & 4 & Part-time & Part-time & Special school teacher & Returned to work after two absence periods. \\
\hline Ruth & 55 & 4 & Full-time & Part-time & Teacher & $\begin{array}{l}\text { Phased return to work. Subsequently went part- } \\
\text { time. Has established an art studio. }\end{array}$ \\
\hline Barbara & 56 & 5 & Not working & $\begin{array}{l}\text { Unpaid } \\
\text { work }\end{array}$ & $\begin{array}{l}\text { Had previously left } \\
\text { employment because of } \\
\text { illness }\end{array}$ & $\begin{array}{l}\text { Took on voluntary work for breast cancer } \\
\text { charity. }\end{array}$ \\
\hline
\end{tabular}




\begin{tabular}{|l|l|l|l|l|l|l|}
\hline Andrea & 57 & 7 & Full-time & $\begin{array}{l}\text { Unpaid } \\
\text { work }\end{array}$ & Teacher & $\begin{array}{l}\text { Retired early. Took on voluntary work as a } \\
\text { trainer for breast cancer charity and part-time } \\
\text { work delivering leaflets. }\end{array}$ \\
\hline Joy & 62 & 1 & Not working & Not working & $\begin{array}{l}\text { Had 'retired' prior to } \\
\text { diagnosis }\end{array}$ & Considering voluntary work for cancer charity. \\
\hline
\end{tabular}

Table 1: Research participants' work histories from diagnoses to interviews. 
The first author conducted the semi-structured interviews either in the participants' homes (n12), offices (n2), or in public spaces (café or social club) (n8). Each interview explored questions regarding the woman's experience and sense-making of her biographical disruption, and current and prospective situation. Interviews lasted between 50 and 240 minutes and were digitally recorded and transcribed in full. With their informed consent, interviewees responded to open-ended questions by telling their stories of their experiences since their diagnosis. This approach allowed them to talk widely and freely about their breast cancer experiences, convey emotions and reflexively foreground what was most important to them (Cresswell, 2007; Riessman, 1993). However, prompts were used to ensure that similar topics were covered, thus better enabling comparison across the sample (Conrad, 1990). Although one prompt asked about relationships at work, this was not universally used, and work was not otherwise asked about.

Initial analysis of the dataset revealed that the breast cancer experience could not be isolated from the broader lived experience that included work and employment roles and responsibilities as well as those of the family unit (Ramarajan and Reid, 2013; Wilson, 2007). Narrative analysis was conducted in parallel by the authors, independently identifying references to work and employment within the transcripts. The authors regularly compared and discussed emergent recurring lower-level themes (Miles and Huberman, 1994). Participants discussed work in numerous ways including domestic work and prior work experiences. The researchers decided to address only work performed outside the home in the exploration of participants' relations with work and self-identity. Through the analysis process various factors that influence the shaping, revision, and innovation of participants' self-identity in relation to work were identified. These are discussed under three themes: i) 
workplace experiences and challenges of return ii) self-identity protection iii) self-identity reflexivity, revision and renewal.

\section{Findings}

Analysis of the dataset revealed that most of the participants who were in paid employment when diagnosed took clinically-legitimised absences from work during and after treatments, and most were employed in gainful work when interviewed (Figure 1).

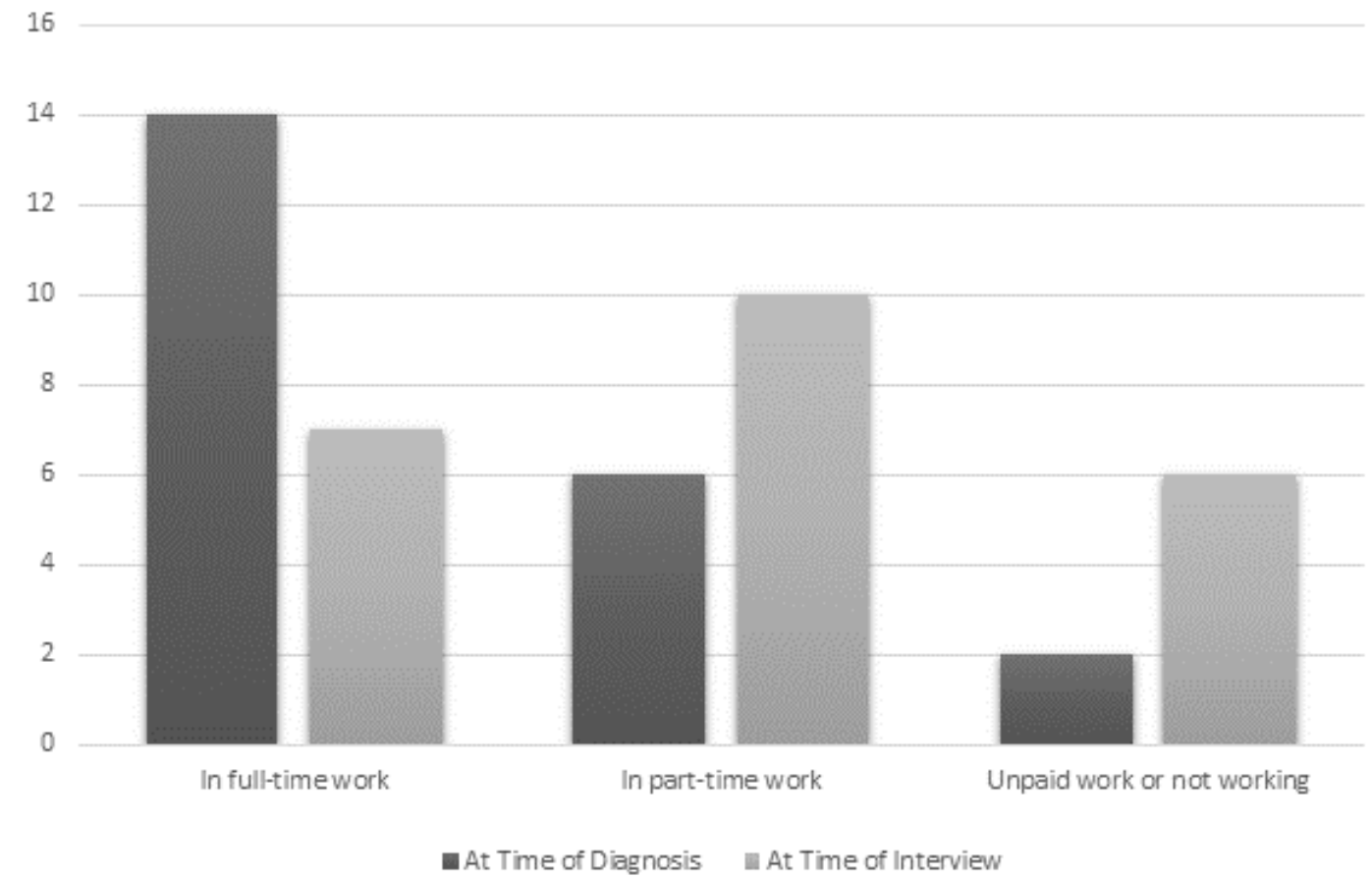

Figure 1. Change in work status of research participants.

This finding accords with other studies (Banning, 2011; Tamminga, 2011; Tiedtke, 2012) that show that, following treatment for early breast cancer, women are likely to resume former employment. More significantly, the findings reveal that women are likely to decisively assert agency over their working circumstances. 


\section{i). Workplace experiences and challenges of return}

Several participants described their efforts to achieve provisions accorded under the Equality Act 2010. For example, Kate acknowledged that her university employer had been 'very good' for sanctioning working from home during the chemotherapy period but also recognised that this had consequences: 'I might work seven days a week to get my hours in ... I was just so tired, and I had to work.' Ruth, a teacher, spoke of the importance of management provisions for smoothing her return to work: 'The school was brilliant... Somebody from HR [Human Resources] came and talked to me about having phased reentry.' While Ruth reported that helped her, other participants reported inconsistencies in support at local management level. For example, Phoebe, a librarian described being unable to return to 'normal duties' due to physical changes resulting from surgery. Showing no visible signs of illness, she found managers and colleagues unwilling to accommodate her restricted abilities. She described experiences of neglect and bullying:

I kept saying, “Can I have an appointment with Occupational Health?” ... This went on for about a year... the bullying... and I had all that stress... As soon as I went to Occupational Health... it was: "It goes without saying, you're not going to do shelving."

Wendy, a nurse-manager, described her experience of a phased return to work: 'The first couple of weeks weren't too bad and then all-of-a-sudden: Wham! It was like I'd never had surgery, never been off work.' Wendy revealed she needed continued support at workplace level once the normal work pattern had resumed. Similarly, Karen, a social worker still undergoing chemotherapy when interviewed, was concerned that the 'huge support' given by her employer thus far would be temporary: 
My manager has said... she'll still give me lighter duties... But people say to me, “Oh, this kindness is only time-limited to when you finish chemo!"”... It's not that at the end of chemo everything's gonna be alright, you know.

Karen was apparently afforded the benefits of the sick role while undergoing chemotherapy treatment (where hair loss signified her illness to colleagues) but feared that once her hair returned she might be considered 'well' enough to resume full duties. Participant Sam reported that her employer 'wouldn't take me back full-time'.

I've got a lot of weakness now and... I've had to change my role. They're saying... there isn't enough work there to substantiate being full-time... I'd said, 'I want to come back on a phased return... until I start to get my energy levels back'... But they wouldn't have it. But when you've been through cancer... I can't be doing with having a big disciplinary thing... cos they're gonna have all the best lawyers.

Here, Sam revealed feeling unjustly treated by her employer's (likely illegal) deployment of organisational power.

Other participants reported difficulties with organisational sick leave processes. Nina's report illustrates:

There was no room on the database to put 'cancer'. It's classed as 'a chest infection'... I said to them, "If I leave and my new employer asks for my records... they're gonna think, "Oh my God, if she's going to be off for six months with a chest infection, that's [high risk]."

In another example, Sam, reported that her line-manager had not contacted her during her absence:

The director of the department phoned me... He said, "Don't be too hard on her [linemanager], she's finding it difficult, she doesn't know what to say." I said, "She's 
finding it difficult? What about $m e$ ?.. If she hasn't got the courtesy... to even pick up the phone I'd seriously question whether she's in the right position... It's like going back to Biblical times where they shunned people. How can people be so cruel?

These illustrations of a lack of consideration in employer processes and by individual line managers are accompanied by reports of co-workers similarly acting insensitively. Malaika, who worked in a fast-food takeaway, said: 'We were in the kitchen... and [the chef] said, “Can I ask you why you've got one breast so obviously smaller than the other?” And I remember being horrified.’

These narratives indicate that women returning to work can find their self-identity challenged or undermined through their encounters with authority figures or colleagues who often implicitly place time-limits on their support (Yarker et al., 2010). Considered together, they resonate with Beck and Beck-Gernsheim's (2002) theorising of 'the breakdown biography' as their frailty and altered physicality was revealed at work. The narratives suggest that this common revelation of frailty required women to reflexively respond via strategies of acceptance or resistance to the sick role (Parsons, 1951).

\section{ii) Self-identity protection}

Martha, a university manager, described a struggle to protect and maintain her established self-identity while she experienced the disruptions incurred by her cancer diagnosis and treatment:

You're having to change all your ideas of what you can do, which then affects ideas of who you are... You sit in the hospital waiting rooms... The fact that you might want to get back to work was completely irrelevant. You had to fit in to their [hospital] timing. 
For Martha, being controlled by hospital management processes challenged her self-identity as a manager skilled at controlling events. She felt diminished as though only permitted a sick-role identity and made an effort to resist that and protect her preferred self and socialidentification by wearing 'smart suits' to hospital appointments to indicate that she had a career and to try to distance herself from 'the others' waiting for treatment: 'It was the notion of identity and who I was'. Martha tried to refuse a 'cancer victim' ascribed identity and, to protect her self-identity, she returned to her work role as quickly as possible.

Others reported similar effort to protect self-identity as they perceived challenges or threats. Karen explained she had continued working as a social worker during treatment for reasons related to identity continuity (Kulkarni, 2019): 'You can't disguise I've got cancer, but I think that's why I needed to go back to work...[Cancer's] a big part of me at the moment but it's just a part of who I am, and I try to get on with what I can do'. She did not want to lose her pre-illness self-identity and work role even as she acknowledged irreparable changes to herself. Similarly, Gabrielle described how, 'to retain normality', she tried to carry on working at her own alternative healing practice while undergoing treatment:

My mum said, "You're sick'. I said, “Oh, I'm alright”... I was still going through chemo and I hadn't had a good week, but... I couldn't bear lying in bed being ill... But, actually, my body needed that time.

For Gabrielle, 'lying in bed' and accepting being ill (Gabe et al, 2004) challenged her selfidentity. She wanted to resist that threat: 'I think people want you to be ill..., in a strange sort of way.' She eventually decided that her work life was unsustainable 'because... you have to be... feeling well if you are dealing with other people's stuff, and I wasn't'. Gabrielle reported that post-treatment she took part-time jobs with a homelessness charity (paid) and a mental health charity (unpaid). Those altered work roles enabled her to both protect and 
revise her self-identity that included the value of working to care for others. For Martha, however, resisting the sick role and identity was costly:

'I worked all the way through radiotherapy, went out for the treatment and came back in. I was stupid. There's no wonder I was so tired... it's absolute exhaustion...'

Here, Martha points to a self-identity struggle to resolve a tension between recognising that radiotherapy left her too exhausted to work and not wanting to relinquish her work role identity that was important to her.

Other participants expressed initial efforts to protect established identities and reassert a pre-diagnosis work role. For many, like schoolteacher Ruth, who had taken a phased return to work, that initial effort was revised in subsequent months. She decided to reduce her working hours:

'I'm part-time now... teaching is such a full-on job [and]... I had terrible depression when normality resumed... Some people say, "Oh, you should give up teaching," but... I'm not going to be pushed, I'll go when I'm ready.'

Ruth revealed that alongside reducing her hours she had established an art studio that gave expression to another, under-developed, aspect of her self-identity. That enabled both protection from identity breakdown and assertion of self-identity renewal. Her reflexivity fostered the agency she asserted so that identity and biography fitted well together (Bauman, 2001). She concluded: 'I don't know if I'll be able to make any money out of it, but it's something nice to do.'

\section{iii) Self-identity reflexivity, revision and renewal}

Confirming extant research (Petersen et al., 2018; Sanders et al. 2019; Yarker et al., 2010) many participants reflected on self-awareness of impaired physical capabilities to perform their jobs following treatments. For example, Connie reported her loss of upper body strength 
resulting from surgery prompted her leaving her job as a swimming instructor: 'I couldn't do it now. I couldn't do the rescue side of things.' Similarly, Carol's reason for leaving her printing job was her self-perception that she could no longer meet the physical requirements of the work: 'I went back, and I thought, 'This is no good.' I couldn't do it, because you have... heavy stacks of paper... I said I have to give it up'. Tina similarly reported on how she had reflected on her capability to do her job as a special-needs teacher: 'Disabled children... can be very physical sometimes... The thought of somebody bumping into me, you know, a sore bit. Then... a couple of years after my treatment I started having panic attacks.' The identity work of these three participants on returning to work entailed reflecting upon the compatibility of their occupations with their altered physicality and (self-perceived) frailty. They initiated adjustment and new developments to their biographical 'life projects' accordingly.

For some participants, biographical disruptions led to decisions to work to support the 'cancer community.' For example, Connie, who could not return to her swimming instructor job, decided it was important for her to develop a new work identity: 'You've got to do something positive because if you don't it will drag you down.' Connie described immersing herself in fundraising for the ward where she was treated and presented press cuttings detailing this work. Similarly, Andrea, who retired as a schoolteacher when diagnosed, described volunteering as a trainer for a breast cancer charity: 'You have to be active and do things that are positive, then at least you're not feeling like you've been victimised.'

Catherine similarly revealed changed priorities and corresponding decision-making. After having left her charity-sector job, she had recast herself in a role supporting others facing similar 'critical situations' (Bury, 1982:169; Sveningsson and Alvesson, 2003): 
I've put together a workshop I can do with women who are recovering from breast cancer to focus on achieving your highest priorities. Because it's that existential stage that people find themselves at, don't they?

In alignment with Eisenstein's (2001:127) reflection that 'my cancer is not just about my body but involves women as a group more broadly' such activities, that were reported by several participants, enabled women to retain a 'collective identity that... is more than simply personal' but now expressed from the more positive perspective of a work identity. From this liminal insider/outsider position (Beech, 2011) they could 'use new activities to structure life' (Rasmussen and Elverdam, 2008:1237) into a future free of the stigma of cancer (Scambler, 1991; Stergiou-Kita et al., 2016). Via self-identity work, they were privileging their emotional needs (Parry, 2003) and actively reshaping their biographies to 'fit' their revised identities. Their exercising agency in taking significant decisions to alter work and career paths included taking up other work and non-work activities as implicit markers of a refusal to be 'victimised' by cancer or compelled to resume a pre-diagnosis 'normality' (Mukherjee, 2011).

Participants, who also spoke of their concerns about cancer recurrence (Trusson, 2013), face and take significant work-related decisions. For example, Nina decided to alter her work routines and reduce her working hours 'to enjoy my granddaughter... because I think I'd get more pleasure out of that.' Such decisions illustrate how biographical disruption to 'plans for the future' (Bury, 1982:169), and reflexivity concerning biographical priorities result in agentic efforts to craft a bridge between, on the one side, a disrupted biography and a disrupted sense of work capability and self-identity and, on the other side, re-crafted life aspirations.

That bridging effort, however, often entailed facing challenges. These included having to surmount a loss of confidence. For example, Sam, who when interviewed was 
awaiting breast reconstruction surgery necessitating a long recovery period, reported that she wanted 'to look for other jobs and explore different things' but lacked the confidence to do so 'because there's no way I could start somewhere new and then say to them, "Oh by the way I'm going to need three months off because I'm having a big operation".' The effort also often included self-management of intense emotions. For example, Wendy, a nursing manager, reported an incident soon after returning to work:

I'm a fairly calm person... and I remember thinking I wanted to scream, “Don't you know what I've bloody been through?... And all you're doing is coming to me with your problems and putting deadlines on me... Do you realise how this has totally changed my life? My life will never be the same, ever again.”

Wendy wanted colleagues to acknowledge that cancer had fundamentally disrupted her life. Moreover, she expressed being faced with a situation of emotional dissonance: i.e. a gap between her 'professional' self and her 'natural' feeling self (Hochschild, 1983; O'Brien and Linehan, 2019). This demanded of her 'emotional work' to manage her post-cancer experience and emotions at work (Cranford and Miller, 2013) while striving to resume her pre-cancer professional role. Similarly, Karen, a social worker, illustrated the emotional tensions of managing normal work demands and her own struggles with positivity and selfidentity alteration even as she tried to work through her cancer treatment. She described putting on a 'smiley face' mask (Goffman, 1969) to create an illusion of positivity yet, as she revealed, this mask had recently slipped: 'I just had to walk out the room and burst into tears'. Karen indicated being self-aware of her present fragility, and how her breast cancer experiences had disrupted how she perceived her future: 'Work has been my most pressing thing... too much, real crappy cases, and if that happens again... I'll go and find another job.' 


\section{Discussion}

The study reveals how the biographical disruptions of breast cancer diagnoses and treatments can precipitate particular self-identity reflexivity in contexts in which work roles, relationships and routines are disturbed and altered. The women reported their desire and agentic effort to reflexively revise and recraft their self-identity narratives. Prominently, they reflected on the role and priority of their employed (including self-employed) work in considering their self-appraised physical capability or frailty and confidence to perform work tasks, and appraisal of workplace relations and support. Participants proactively made changes to work roles and routines (including self-initiated reduced hours: Figure 1 illustrates a shift away from full-time work arrangements amongst the research population). These changes sought to resolve tensions resulting from self-appraised altered capabilities or organisational or occupational commitment. Beyond identity and health disruption the participants strove to shape their preferred self-identity as women and as workers.

Each individual's reflexive project (Giddens, 1991), following and stimulated by the biographical disruption of cancer, included: responding to her perceptions of social identifications (e.g. engagement with 'the sick role'); making efforts to reconcile her altered self-narrative with her work identity; and shaping her desired future relations with her work and other life priorities. These three-fold elements depict an individual's craft - of labour and of art - of an innovated self-identity and work-identity. Reflexivity and revision lead to new actions that shape the biographical future. This process of recrafting an individual's selfidentity and reshaping relations to paid work - whether in altering work roles, hours, or tasks - occurs over time and unevenly.

The variance of workplace experiences reported suggests that women working during and after cancer treatments must navigate a less predictable work landscape. They may encounter various behaviours from managers or co-workers, ranging from acts of compassion 
(e.g. the 'huge' support Karen reported) (Lilius et al., 2008) through ambivalence, intrusiveness and insensitivity to stigmatising, shunning and bullying (Malaika's, Phoebe's and Sam's experiences). As well, women may require more conscious self-constraint of their emotions to conceal stressors of their cancer journey (e.g. Wendy's experience) (Yoo et al., 2010).

The narratives reveal considerable complexity in the self and work identities of women working during and after breast cancer treatment. These complexities, along with challenges of continuing treatments, indicate that return to work, while an empirically visible event occurring through management-agreed phases, is a more complex matter entailing various factors. The liminality between sickness (sick role) and wellness (fit role) appears to persist over a longer period of time. Women may self-shape multiple 'returns to work' as they reflexively navigate between work, former sick role identities, and altered biological condition (e.g. physical impairment, empirical risk of cancer recurrence).

Parsons' (1951) classic sick role theory retains validity in regard to how employers and organisations implicitly regard as binary 'sickness' and 'fitness' at work. However, this study demonstrates rich utility in Bury's (1982) biographical disruption theory. Women might simultaneously inhabit both roles or float between the two, for example, working from home during treatment periods or displaying illness-related frailty at work (Gabe et al., 2004; Tiedtke et al., 2012; Stergiou-Kita et al., 2016). Importantly, it shows that following biographical disruption, workers strive to integrate self-identity and existential tasks with their work and social contribution. For many of the participants this entailed responding to biographical disruption by enacting agency to change their work patterns, and for some, to seek meaningful work activities outside the paid labour market to fulfil emotional rather than material needs (McKay et al., 2013; Parry, 2003; Taylor, 2015). 
Given that more working-age women are returning to work after breast cancer, this study has significant implications for social and organisational management policy. Specifically, it invites a shift towards a social - and organisational - acceptance of breast cancer being an illness that may be encountered within a continuing career path and that may remain impactful on women's working lives thereafter. It invites setting aside media-driven master narratives, for example, of pink-ribboned 'survivors' seamlessly re-shouldering life and work tasks, and instead listening to personal narratives (Nielsen, 2019). These shifts may help women to navigate their personal experiences of disruption resulting from breast cancer diagnosis and treatments, and assist them in biographical recrafting. Recognition is emerging within the Human Resource Management (HRM) profession that organisations need to support employees affected by cancer (MacMillan, 2019), not least to avoid legal claims of harassment and discrimination. This study suggests that this recognition needs to permeate further across the broader working population, especially to line managers of staff who have been treated for breast cancer.

\section{Conclusion}

This study shows how women experiencing the biographical disruption of breast cancer in the course of their working lives strive to revise and innovate their self-identity, and work identity, in the midst of personal and social constraints in their workplaces. In these identity transitions (Kulkarni, 2019) they craft their breast cancer disruptive experiences and subsequent workplace experiences into new developments of who they are, and want to be, as persons and as workers. The study also shows that this process occurs over time in a fashion that is specific to each individual. That variability calls into question current expectations in much work, employment and HRM literature that a phased return to work adequately addresses a presumed transition from sickness to fitness to work. 
This article contributes to richer understanding of the role of reflexive self-identity and work. It particularly advances knowledge about the intersections of biographical disruption, self-identity and gender with relations toward work and employment. Furthermore, it raises implications for practical interventions in management and employment policies. HRM processes and practices that facilitate greater attention being paid to the lived realities of employees returning to work during and after treatments (i.e. beyond possession of a 'fit note') are required. Consequently, organisational adjustments, personalised accommodation of individual workers within their work setting, and separate recording of sickness and cancer disability-related absence (Disability Confident/CIPD, 2018) can be effectively undertaken.

\section{References}

Andringa W, Nieuwenhuis R and Van Gerven M (2015) Women's working hours: The interplay between gender role attitudes, motherhood, and public childcare support in 23 European countries, International Journal of Sociology and Social Policy, 35(9/10): 582-599. Alvesson M and Billing YD (2009) Understanding Gender and Organizations (2 ${ }^{\text {nd }}$ Edition). London: Sage.

Alvesson M and Kärreman D (2007) Unravelling HRM: Identity, ceremony and control in a management consulting firm. Organization Science 18(4): 711-723.

Amir Z, Neary D and Luker K (2008) Cancer survivors' views of work 3 years post diagnosis: a UK perspective. European Journal of Oncology Nursing 12(3): 190-197.

Atkinson W (2016) Beck's unintended legacy for class analysis. Work, Employment and Society 30(5): 892-894. 
Baker P, Beesley H, Fletcher I, Ablett J, Holcombe C, and Salmon P (2014) 'Getting back to normal' or 'a new type of normal'? A qualitative study of patients' responses to the existential threat of cancer. European Journal of Cancer Care 25(1): 180-189.

Balmer C, Griffiths F and Dunn J (2014) A qualitative systematic review exploring lay understanding of cancer by adults without a cancer diagnosis. Journal of Advanced Nursing 70(8): 1688-1701.

Banning M (2011) Employment and breast cancer: a meta-ethnography. European Journal of Cancer Care 20(6): 708-719.

Bauman Z (2001) The Individualized Society. Cambridge: Polity Press.

Beck U and Beck-Gernsheim E (2002) Individualization: Institutionalized individualism and its Social and Political Consequences. London: Sage.

Beech N (2011) Liminality and the practices of identity reconstruction. Human Relations 64(2): 285-302.

Blyton P and Jenkins J (2012) Life after Burberry: shifting experiences of work and nonwork life following redundancy. Work, Employment and Society 26(1): 26-41.

Brown AD (2015) Identities and Identity Work in Organizations. International Journal of Management Reviews 17(1): 20-40.

Bury M (1991) The sociology of chronic illness: a review of research and prospects. Sociology of Health and Illness 13(4): 451-468.

Bury M (1982) Chronic illness as biographical disruption. Sociology of Health \& Illness 4(2): 167-182.

Casey C (1995) Work, Self and Society after Industrialism. London: Routledge. 
Chandler J (2017) Identity at Work. Abingdon: Routledge.

Conrad P (1990) Qualitative research on chronic illness: A commentary on method and conceptual development. Social Science \& Medicine 30(11): 1257-1263.

Cooper AF, Hankins M, Rixon L, Eaton E and Grunfeld EA (2013) Distinct work-related, clinical and psychological factors predict return to work following treatment in four different cancer types. Psycho-Oncology 22(3): 659-667.

Cranford CJ and Miller D (2013) Emotion management from the client's perspective: the case of personal home care. Work, Employment and Society 27(5): 785-801.

Cresswell JW (2007) Qualitative Inquiry and Research Design. Thousand Oaks: Sage.

Crompton R and Harris F (1998) Explaining Women's Employment Patterns: 'Orientations to Work' Revisited. British Journal of Sociology 49(1): 118-136.

CRUK [Cancer Research UK] (2020) Cancer Statistics for the UK. Available (consulted 5 February, 2020) at: http://www.cancerresearchuk.org/health-professional/cancer-statisticsfor-the-uk

Disability Confident/CIPD (2018) Recruiting, managing and developing people with a disability or health condition: A practical guide for line managers. London: Department for Work and Pensions.

Dobbins T, Plows A and Lloyd-William H (2014) 'Make do and mend' after redundancy at Anglesey Aluminium: critiquing human capital approaches to unemployment. Work, Employment and Society 28(4): 515-532.

Doherty M (2009) When the working day is through: the end of work as identity? Work, Employment and Society 23(1): 84-101. 
Ehrenreich B (2009) Smile or Die: How Positive Thinking Fooled America and the World. London: Granta.

Eisenstein Z (2001) Manmade Breast Cancers. Ithaca, NY: Cornell University Press.

Foster D (2007) Legal obligation or personal lottery? Employee experiences of disability and the negotiation of adjustments in the public sector workplace. Work, Employment and Society 21(1): 67-84.

Foster K (2012) Work, narrative identity and social affiliation. Work, Employment and Society 26(6): 935-950.

Foubert J, Levecque K and Van Rossem R (2016) Feeling well while chronically ill or impaired: a multilevel study on the moderating role of employment and volunteering in Europe. Disability \& Society 32(1): 17-36.

Gabe J, Bury M and Elston MA (2004) Key Concepts in Medical Sociology. London: Sage.

Gardiner J, Stuart M, MacKenzie R, Forde C, Greenwood I and Perrett R (2009) Redundancy as a critical life event: moving on from the Welsh steel industry through career change. Work, Employment and Society 23(4): 727-745.

Giddens A (1991) Modernity and Self-Identity: Self and Society in the Late Modern Age. Cambridge: Polity.

Glauber R (2011) Limited Access: Gender, occupational composition, and flexible work scheduling. The Sociological Quarterly 52(3): 472-494.

Godfrey M, Price S and Long A (2018) Unveiling the maelstrom of the early breast cancer trajectory. Qualitative Health Research 28(4): 572-586.

Goffman E (1969) The Presentation of Self in Everyday Life. Harmondsworth: Penguin. 
Hall S (1992) The question of cultural identity. In: Hall S, Held D and McGrew T (eds)

Modernity and its Futures. Cambridge: Polity Press, 274-316.

Hochschild A (1983) The Managed Heart: Commercialization of Human Feeling. Berkeley, CA: University of California Press.

Hoyer P and Steyaert C (2015) Narrative identity construction in times of career change: Taking note of unconscious desires. Human Relations 68(12): 1837-1863.

Ibarra H and Barbulescu R (2010) Identity as Narative: Prevalence, Effectiveness, and Consequences of Narrative Identity Work in Macro Work Role Transitions. Academy of Management Review 35(1): 135-154.

Johnsson A, Fornander T, Rutqvist LE and Olsson M (2010) Factors influencing return to work: a narrative study of women treated for breast cancer. European Journal of Cancer Care 19(3): 317-323.

Kaptein AA, Schoones JW, Fischer MJ, Thong MS, Kroep JR and van der Hoeven KJ (2015). Illness Perceptions in Women with Breast Cancer: A Systematic Literature Review. Current Breast Cancer Report 7(3): 117-126.

Kennedy F, Haslam C, Munir F and Pryce J (2007) Returning to work following cancer: a qualitative exploratory study into the experience of returning to work following cancer. European Journal of Cancer Care 16(1): 17-25.

Kulkarni M (2019) Holding on to let go: Identity work in discontinuous and involuntary career transitions. Human Relations (OnlineFirst) https://doi.org/10.1177/0018726719871087

Lally R and Underhill M. (2012) Transition to breast cancer survivorship: a longitudinal qualitative follow-up study of two-year survivors. Journal of Psychosocial Oncology 30(1): 97-127. 
Lilius JM, Warline MC, Maitlis S, Kanov J, Dutton JE and Frost P (2008) The contours and consequences of compassion at work. Journal of Organizational Behavior 29(2): 193-218.

Little M, Sayer, E-J, Paul K and Jordens C (2000) On surviving cancer. Journal of Sociology of Medicine 93(10): 501-502

McKay G, Knott V and Delfabbro P (2013) Return to work and cancer: The Australian experience. Journal of Occupational Rehabilitation 23(1): 93-105.

MacKenzie R and Marks A (2019) Older workers and occupational identity in the telecommunications Industry: Navigating employment transitions through the life course. Work, Employment and Society 33(1): 39-55.

MacMillan Cancer Support (2019) Managing Cancer in the Workplace, 6th Edition. [Booklet produced in partnership with CIPD] Available (consulted 5 February, 2020) at: http://be.macmillan.org.uk/Downloads/CancerInformation/WorkAndCancer/MAC12891Man agingCancerLowresPDF20190520.pdf

Martindale A-M and Fisher P (2019) Disrupted faces, disrupted identities? Embodiment, life stories and acquired facial 'disfigurement'. Sociology of Health \& Illness 41(8): 1503-1519.

Mickey E and Wingfield A (2019) Race, Identity and Work. Bingley: Emerald.

Miles MB and Huberman AM (1994) Qualitative Data Analysis: An Expanded Sourcebook, 2nd Edition. Thousand Oaks, CA: Sage.

Mukherjee S (2011) The Emperor of all Maladies: A Biography of Cancer. London: Fourth Estate.

Ní Léime Á, Street D, Vickerstaff S, Krekula C and Loretto W (eds) 2017. Gender, Ageing and Extended Working Life: Cross-National Perspectives. London: Policy Press. 
Nielsen E (2019) Disrupting Breast Cancer Narratives: Stories of Rage and Repair. Toronto: University of Toronto Press.

O'Brien E and Linehan C (2019) Problematizing the authentic self in conceptualizations of emotional dissonance. Human Relations 72(9): 1530-1556.

Parry J (2003) The Changing Meaning of Work: Restructuring in the Former Coalmining Communities of the South Wales Valleys. Work, Employment and Society 17(2): 227-246.

Parsons T (1951) The Social System. London: Routledge and Kegan Paul.

Petersen K, Momsen A, Stapelfeldt C, Olsen P and Nielsen C (2018) Return-to-work intervention during cancer treatment - The providers' experiences. European Journal of Cancer Care 27(2): e12793.

Powers N, Gullifer J and Shaw R (2016) When the treatment stops: a qualitative study of life post breast cancer treatment. Journal of Health Psychology 21(7): 1371-1382.

Pudrovska T (2010) Why is Cancer More Depressing for Men than Women among Older White Adults? Social Forces 89(2): 535-558.

Ramarajan L and Reid E (2013) Shattering the myth of separate worlds: Negotiating nonwork identities at work. Academy of Management Review 38(4): 621-644.

Rasmussen DM and Elverdam B (2007) Cancer survivors' experience of time - time disruption and time appropriation. Journal of Advanced Nursing 57(6): 614-622.

Riach K and Loretto W (2009) Identity work and the 'unemployed' worker: age, disability and the lived experience of the older unemployed. Work, Employment and Society 23(1): 102-119.

Riessman CK (1993) Narrative Analysis. Newbury Park, CA: Sage. 
Sanders T, Elliott J, Norman P, Johnson B and Heller S (2019) Disruptive illness contexts and liminality in the accounts of young people with type 1 diabetes. Sociology of Health \& Illness 41(7): 1289-1304.

Scambler G (1991) Deviance, Sick Role and Stigma. In: Scambler, G (ed) Sociology as Applied to Medicine, 6th Edition. Edinburgh: Saunders Elsevier, 205-217.

Shakespeare T (1996) Rules of Engagement: Doing Disability Research. Disability and Society 11(1): 115-119.

Silverman D (2010) Doing Qualitative Research, 3rd Edition, London: Sage.

Stahl G (2015) Identity, Neoliberalism and Aspiration: Educating white working-class boys. Abingdon: Routledge.

Stergiou-Kita M, Pritlove C and Kirsh B (2016) The "Big C" - stigma, cancer, and workplace discrimination. Journal of Cancer Survivorship 10(6): 1035-1050.

Strangleman T (2012) Work identity in crisis? Rethinking the problem of attachment and loss at work. Sociology 46(3): 411-425.

Sveningsson S and Alvesson, M (2003) Managing managerial identities: organizational fragmentation, discourse and identity struggle. Human Relations, 56(10): 1163-1193.

Tamminga SJ, De Boer A, Verbeek J and Frings-Dresen M (2012) Breast cancer survivors' views of factors that influence the return-to-work process - a qualitative study. Scandinavian Journal of Work Environment \& Health 38(2): 144-154.

Taylor R (2004) Extending conceptual boundaries: work, voluntary work and employment. Work, Employment and Society 18(1): 29-49 
Taylor R (2015) Volunteering and unpaid work. In: Edgell, S, Gottfried, H, Granter, E (eds) The SAGE Handbook of the Sociology of Work and Employment. London: SAGE pp. 485501.

Tiedtke C, de Rijk A, Donceel P, Christiaens M-R and Dierckx de Casterlé B (2012) Survived but feeling vulnerable and insecure: a qualitative study of the mental preparation for RTW after breast cancer treatment. BMC Public Health 12: article 538.

Tighe M, Molassiotis A, Morris J and Richardson J (2011) Coping, meaning and symptom experience: A narrative approach to the overwhelming impacts of breast cancer in the first year following diagnosis. European Journal of Oncology Nursing 15(3): 226-232.

Trusson C and Woods F (2016) 'An end to the job as we know it': how an IT professional has experienced the uncertainty of IT outsourcing. Work, Employment and Society 31(3): $542-552$.

Trusson D (2013) Living With a New Normal: Women's Experiences Following Treatment for Early-Stage Breast Cancer or DCIS (Doctoral dissertation, University of Nottingham).

Trusson D, Pilnick A and Roy S (2016) A new normal?: Women's experiences of biographical disruption and liminality following treatment for early stage breast cancer, Social Science \& Medicine 151: 121-129.

Trusson D, and Pilnick A (2017) Between stigma and pink positivity: Women's perceptions of social interactions during and after breast cancer treatment, Sociology of Health \& Illness 39(3): 458-473.

Watson TJ (2008) Managing Identity: Identity Work, Personal Predicaments and Structural Circumstances, Organization 15 (1): 121-143.

Watson TJ (2012) Sociology, Work and Organisation, $6^{\text {th }}$ Edition. Abingdon: Routledge. 
Wildman JM (2020) Life-Course Influences on Extended Working: Experiences of Women in a UK Baby-Boom Birth Cohort. Work, Employment and Society 34(2): 211-227.

Wilson S (2007) 'When you have children, you're obliged to live': motherhood, chronic illness and biographical disruption. Sociology of Health \& Illness 29(4): 610-626.

Yarker J, Munir F, Bains M, Kalawsky K and Haslam C (2010) The role of communication and support in return to work following cancer-related absence. Psycho-Oncology 19(10): 1078-1085.

Yoo GJ, Aviv C, Levine EG, Ewing C and Au A (2010) Emotion work: disclosing cancer. Supportive Care in Cancer 18(2): 205-215.

Zou M (2015) Gender, work orientations and job satisfaction. Work, Employment and Society 29(1): 3-22. 